José Ignacio HERNÁNDEZ G.

Monteávila University

Central University of Venezuela

Andrés Bello Catholic University

\title{
THE CROSSROADS OF DEMOCRACY \\ IN VENEZUELA: THE EMERGENCE \\ OF THE POPULAR POWER
}

ABSTRACT The paper analyzes one of the main political instruments of the current regime of President Chávez in Venezuela: the Popular Power, as a new conception of democracy within socialist model. We studied the origins of such instrument and its current legal framework, in order to demonstrate how Popular Power constitutes a violation of constitutional concept of democracy, due to its lack of freedom and pluralism. The Popular Power is articulated in the Laws promulgated in 2010, as an organization that acts under the political control of the National Government, with the sole purpose of the consolidation of the socialism and the construction of a "new" State, the "Communal State". According to the Laws of the Popular Power, socialism is not only the political doctrine of the Government's party, but also the political doctrine of the State, that excludes any form of political participation different to the ones executed through the organizations of the Popular Power and for the promotion of socialism. In the end, the emergence of the Popular Power in Venezuela demonstrates the risk of the manipulation of the language of democracy for political purposes that are the antithesis of democracy.

KEY WORDS Democracy, pluralism, representative regime, participatory democracy, socialism, Popular Power, Hugo Chávez, Venezuela. 


\section{INTRODUCTION}

Venezuela was considered, for many years, the longest-lasting democracy in Latin America. After the long dictatorship of Juan Vicente Gómez (1908-1935) and the transitory regimes of the military governments of Eleazar López Contreras and Isaías Medina Angarita (1935-1945), the coup d'état in 1945 brougth for the first time ever in Venezuelan history the legal basis for the implementation of democratic system: the Electoral Statute of 1946, which recognized the right for the universal vote of all the citizens. ${ }^{1}$ And in 1948, also, for the first time, a President was elected in a democratic voting: Rómulo Gallegos, a celebrated novelist. But in the very same year, a new coupd' état - commanded by the military chiefs involved in the coup of 1945 - leaded to a new military dictatorship for the next ten years. ${ }^{2}$

In January, 1958, the dictator, Marcos Pérez Jimenez, left the country. At this time, the main political parties understood that a political pact was necessary in order to guarantee the stability of the upcoming democracy. The parties signed the Pact of Punto Fijo, which settled the rules of the Venezuelan democracy, sustained in the representative regime. The representative regime was later established in the Constitution of 1961, with the political party as the main vehicle to promote the democratic participation of the citizen. The new Constitution incorporated the fundamentals principles of separation of powers, Rule of Law and protection of constitutional rights. And, under the supremacy of the Constitution, the democracy in Venezuela was developed. ${ }^{3}$

However, with the years, the representative regimen resulted in a centralized system in which the President concentrated wide powers and the political parties monopolized the participation of the citizen. The existence of a strong Executive Power was conceived as a necessity in the early days of democracy to avoid military attempt against the new constitutional order. But this system should have evolved in a decentralized and more democratic regime. On the contrary, the democracy in Venezuela formed a "State of parties" (Estado de partidos) under the strong conduction of the President. ${ }^{4}$

In addition, the National Executive exercised extensive powers of regulation in the economy, due to the "special powers" granted by the Legislators. This caused a permanent administrative intervention in the economy, helped by the dependence of the economy to the oil industry. Since the 30s, oil became the main revenue of the State. In the 70 s, the oil industry was nationalized and as a consequence, the National Executive became the main entrepreneur of the country. The oil was, in this sense, an incentive of the centralized political system in Venezuela. ${ }^{5}$

G. Carrera Damas, La Primera República Liberal Democrática 1945-1948, Caracas 2008, p. 5.

M. Caballero, La historia de los Venezolanos del siglo XX, Caracas 2011, p. 198.

A.-R. Brewer Carías, Historia Constitucional de Venezuela, Vol. 2, Caracas 2008, p. 77.

Compare: A.-R. Brewer Carias, Problemas del Estado de partidos, Caracas 1988.

The Administration in Venezuela has been influenced by the strong dependence of our economy to the oil. See: A. Baptista, El relevo del capitalismo rentistico. Hacia un nuevo balance de poder, Caracas 2004, p. 31. 
This model was not sustainable. As a consequence, a major reform of the State was initiated in 1984 with the creation of the Commission for the Reform of the State which focused its works in two main concerns: (i) the decentralization of the State (as a remedy for the centralization of the National Executive) and (ii) the renovation of the democracy through the implementation of "participatory mechanisms" (as a remedy for the monopoly of the political party). ${ }^{6}$

Those reforms were partially implemented in 1989 with several Laws that promoted the decentralization and the reinforcement of the States of the Federation and the Municipalities. The reforms included also the recognition of the right of the citizens to elect the Governors and Majors. But these reforms did not prevent the collapse of the political system: the two coups of 1992 against the then President Carlos Andrés Pérez demonstrated that democracy had weakened. The following year, the President was removed of his office by a controversial decision of the Supreme Court. ${ }^{7}$ The general consensus of the moment was that the Venezuelan State, due to the collapse of the democratic system based in the centralized "State of parties", was in a "final crisis" that could only be remedied with a new Constitution. ${ }^{8}$ This was the core argument of the presidential candidate in 1998, Hugo Chávez, the former commandant who led the coup of February, 1992. When Chávez was elected in December, 1998, he kept his political offer and promoted a constitutional assembly that not only promulgated a new Constitution (in December, 1999), but also substitutes all the political powers. ${ }^{9}$ With this formula, the President "renovated" the political powers with a new election in which he obtained a majority support.

One of the renowned innovations of the Constitution of Venezuela of 1999 was the formal assumption of a participative democracy instead of a representative democracy. The Constitution recognized the principles of representative regime but also established the foundations of the participative democracy, according to which the citizens had the right to participate directly (not only through representatives) in political matters. ${ }^{10}$ Furthermore, the Constitution incorporated the decentralization as the political form of the State, in order to improve democracy. The goals of the reform of the State that were conceived in the decade of the eighties of the past century were now formally incorporated in the new Constitution.

Consequently, the participative democracy was not a real innovation of the Constitution of 1999 , because in the past decades several reforms were introduced to incorporate mechanism of political participation. Indeed, in 1998 was promulgated the Organic Law of the Suffrage and the Political Participation which regulated legal mechanisms that allowed the direct participation of the citizen in political matters.

6 For a comprehensive analysis of these reforms, see the book coordinated by the Commission: Antecedentes de la reforma del Estado, Caracas 1990.

M. Caballero, La historia de..., p. 341.

$8 \quad$ A.-R. Brewer Carías, Golpe de Estado y proceso constituyente en Venezuela, México 2001, p. 17.

9 Ibid., p. 32.

10 H. Njaim, 'La democracia participativa, de la retórica al aprendizaje', Boletín de la Academia de Ciencias Politicas y Sociales, No 143 (2005), p. 25. 
We must highlight that when Chávez became President, in February 1999, he promulgated a Decree based in this Law, with the purpose of asking the people if they wanted to elect a constitutional assembly. ${ }^{11}$ Nevertheless, the Constitution of 1999 regulated in detail the different expressions of participative democracy. From a formal point of view, the new Constitution enhanced the democracy.

But in 2005 President Hugo Chávez assumed socialism as the ideology of his government. He insisted then on the necessary "disassembly" of the "Liberal State" and, in consequence, the construction of the new "Socialist State" based in the popular and direct democracy of the people. ${ }^{12}$ The representative regime was considered an "obsolete manifestation" of the democracy. If the sovereignty resides in the people, then the people must exercise directly this sovereignty without bureaucratic obstacles, according with this point of view. This was the justification of the creation, in 2005, of the communal council, an organization based on certain community with the purpose of promoting the political participation of the citizen. This vision of the participative democracy turned into the Popular Power, an imprecise and ambiguous expression that intended to describe the direct exercise of democracy by the people. When President Chávez promoted a major reform of the Constitution in 2007, the National Assembly promulgated the Project of Reform of the Constitution that incorporated the Popular Power as a new dimension of democracy, but based in the final goal of the promotion of the socialism. ${ }^{13}$ In fact, the Popular Power - a heterogeneous conglomerate of communal organizations - was the basis of the Communal State in this Project, a socialist form of State, different from the Republic organized in the Constitution of 1999. In this proposal, decentralization was conceived not as the transfer of competences between the National Power and the States of the Federation, but as the direct transfer of competence to the Popular Power in order to reinforce socialism, the only political ideology admitted in the Project. ${ }^{14}$

The Project was rejected by a popular consult in December, 2007. But the development of the Popular Power continued under the "National Plan for the Social and

11 R. Combellas, 'El proceso constituyente y la Constitución de 1999' in E. Plaza, R. Combellas (coords.), Procesos constituyentes y reformas constitucionales en la historia de Venezuela 1811-1999, Vol. 2, Caracas 2005, p. 765.

12 A resume of the ideology of this socialist model, in H. El Troudi, La politica económica bolivariana (PEB) y los dilemas de la transición socialista en Venezuela, Caracas 2010.

13 See: A.-R. Brewer Carías, La reforma constitucional de 2007. (Comentarios al proyecto inconstitucionalmente sancionado por la Asamblea Nacional el 2 de noviembre de 2007), Caracas 2007. Also see: G. Linares Benzo, 'Sólo un Poder Público más. El Poder Popular en la Reforma de 2007', Revista de Derecho Público, No 112 (2007), p. 101.

14 Under the Constitution of 1961, the decentralization was conceived as the transfer of competences from the National level (the Republic) to the States, in order to strength the States and, in consequence, the democracy. The decentralization in the last years of the past century was in Venezuela the new expression of an ancient debate: the assumption of the American federal model. Compare: M. de los Ángeles Delfino, 'La involución de la descentralización' in M. de los Ángeles Delfino, M. Rachadell, Descentralización y Centralización del Poder en Venezuela, Caracas 2009, p. 7, Fundación Manuel García Pelayo, Colección Cuadernos del Centenario, № 11. 
Economic Development 2007-2013", according to which the "Popular Power" must be the new basis of a "protagonist democracy". In practice, President Chávez and the Legislators implemented the proposal contained in Project of constitutional reform through the National Plan, Laws and several regulations. Especially, in 2009 was promulgated a new Organic Law of the Communal Council, that conceived the communal council as an organization for the promotion of the "socialist society". A comprehensive regime of the Popular Power (as it was stated in the Project of Reform of the Constitution) would be issued at the end of 2010 in special conditions that required a brief explanation.

The members of the National Assembly for the period 2005-2010 were elected only from the government party, United Socialist Party of Venezuela, because the opposition decided not to participate in these elections. In September 2010 the political parties of the opposition obtained approximately $40 \%$ of the seats of the National Assembly. The new political composition reduced the faculties of the congressmen of the United Socialist Party of Venezuela in the relevant matters that required a qualified vote, including the promulgation of Organic Laws, a higher category of Law in Venezuela. This motivated the members of the National Assembly elected in 2005 to enact in December $2010 \mathrm{sev}$ eral Organic Laws just a month before the installation of the new Assembly. Among others, were promulgated the Organic Law of the Popular Power, the Organic Law of the Commune, the Organic Law of the Communal Economic System, the Organic Law of the Social Comptroller, and the Organic Law of the Popular Planning. ${ }^{15}$

The legal framework of the Popular Power contemplated several proposal included in the Project of Reform of the Constitution that was rejected in 2007. In the practice, this Project was carried out through several Laws, which demonstrates that those Laws are unconstitutional. According to some authors, this was a constitutional fraud, because major changes in the organization of the State that were contemplated in the Project of Reform of the Constitution, were later implemented through Laws. ${ }^{16}$ One of these changes was the Popular Power that intended to create a new form of State. At the end, the creation of a new State was a consequence of legal reforms.

Precisely, the objective of the paper is to study the legal framework of the Popular Power in Venezuela in order to determine its impact on democracy. In our opinion, the legal configuration of the Popular Power affected the essence of the political participation, a constitutional right based on the freedom of the citizen to choose its own political decisions. For this purpose, I am going to study a brief concept of the democracy according to the Constitution of Venezuela; the nature of the right to political participation and its relation with the representative regime; the legal configuration of the Popular Power, and finally, the necessary reformulation of the conception of the Popular Power.

15 For a comprehensive analysis of the Popular Power, see: Leyes Orgánicas del Poder Popular, Caracas 2010. The books contain several articles about this topic from different points of view.

16 A.-R. Brewer Carías, 'Introducción general al regimen del Poder Popular y del Estado Comunal' in Leyes Orgánicas del..., p. 11. 


\section{DEMOCRACY AND POLITICAL PARTICIPATION UNDER THE CONSTITUTION OF VENEZUELA}

\section{The constitutional concept of democracy}

According to article 2 of the Constitution of Venezuela of 1999, Venezuela is a "Democratic State". Since our first Constitution of 1811 the "Democratic State" had been based on a representative regime, according to the model of the Constitution of the United States of America. The general principle adopted is that sovereignty resides in the people for the election of their own representatives. After our long dictatorships, democracy led to the exercise of the right to vote. ${ }^{17}$ Because of this, in a first approach democracy can be defined as the popular election of representatives. But this is a very incomplete definition.

As Sartori explains, ${ }^{18}$ democracy can be analyzed in a political, economic and social perspective. The political perspective requires the popular election of representatives at the Legislative and Executive Power. The economic democracy refers to the equal participation of the citizens in the economy. The social democracy, finally, refers to the effectiveness of the exercise of social rights. The political democracy is the fundament of the economic and social democracy, because it based in popular sovereignty.

But democracy refers not only to the popular election of representatives. In addition, democracy requires the active participation of the citizens in political decisions under the Rule of Law. According to Bobbio, ${ }^{19}$ democracy depends upon the exercise of the rights that allow the free election of the citizen and the formal rules that guarantees such free election. Democracy requires Rule of Law, because only under Rule of Law the citizens have the right to participate in political decisions. Furthermore, the Rule of Law is based in some fundamental principles, like separation of power; supremacy of the Constitution; subordination of the Government to the Law and the recognition of human rights. Thus, democracy means the limitation of the Government under the Rule of Law. Otherwise, as Manuel García-Pelayo explains, the democracy can degenerates in acts that are contradictory with its meanings, like the attempt to legitimate the action of the State in some "mass acclamation" through the "unitary party". ${ }^{20}$

The "Democratic State" recognized in the article 2 of the Constitution is the State under the Rule of Law, as is stated in the article 3 of the Inter-American Democratic Chart:

M. Caballero, La historia de..., p. 209.

18 G. Sartori, ¿Qué es la democracia?, Madrid 2003, p. 17.

19 N. Bobbio, El futuro de la democracia, México 2008, p. 23.

20 Compare: M. García-Pelayo, 'Las transformaciones del Estado contemporáneo' in idem, Obras Completas, Vol. 2, Madrid 1991. 
Essential elements of representative democracy include, inter alia, respect for human rights and fundamental freedoms, access to and the exercise of power in accordance with the rule of law, the holding of periodic, free, and fair elections based on secret balloting and universal suffrage as an expression of the sovereignty of the people, the pluralistic system of political parties and organizations, and the separation of powers and independence of the branches of government.

Without fundamentals freedom and, in consequence, without Rule of Law, there is no democracy at all. As L. Ferrajoli concludes, is necessary to assume a "multidimensional model" of democracy that integrates its formal perspective (elections) with its substantial perspective (political forms of the exercise of the Government). ${ }^{21}$ This means that democracy must be supported in the recognition and promotion of freedom, and because of this, in the limitation of the Government by the Law.

In Venezuela, the constitutional concept of democracy has been related to the control of the Government, in a very similar position that the one assumed by Madison in the United Stated. ${ }^{22}$ The opposite of democracy is, in consequence, the tyranny, even if is the tyranny of the "democratic majorities". This was one of the main concerns of Tocqueville about the American model of democracy that was assumed in the early days of the Liberal Republic in Venezuela, during the 19th century. This is why one of first constitutional commentator in Venezuela - Francisco Javier Yanes - explained in 1839 that democracy required the respect of fundamental rights and the Rule of Law, in order to avoid any kind of despotism, not only from the Government but also from the majority of the peo$\mathrm{ple}^{23}$. According to this author, even a democratic law can be an oppressive measure if violates freedom, property, equality and security, which are the fundamental rights of the citizen. Yanes explains that, because of this, the obedience to the Law must be a "rational obedience", in order to control the "unfair law". As an additional limitation, Yanes recognized that citizens have the right to directly supervise the Government, because even a democratic-elected government could degenerate in tyranny and in oppression.

This idea, contemplated in our fist Constitution of 1811 , was preserved in our constitutional evolution, even during dictatorial regimes. As a result, the constitutional concept of democracy in Venezuela is supported on several basic principles that make democracy a complex concept. At least, democracy requires the free election of the representatives and the political participation of the citizen. But this is not enough: there are other principles connected with democracy. Democracy requires Rule of Law and, in consequence, the other principles related to such rule.

21 L. Ferrajoli, 'Sobre la definición de democracia. Una discusión con Michelanagelo Bovero', Isonomía, № 19 (2003), p. 227. From this author, also see: idem, Principia iuris. Teoría del derecho y de la democracia, Vol. 2, Madrid 2011, p. 9. The "formal concept" of democracy is focus only in the existence of certain rules that regulates the decision-making process. This is an incomplete concept, because it does not establish limitations about this process. On the contrary, the "constitutional concept" of democracy understands that it is not enough that such rules exists. In addition, even the popular sovereignty must be limited power under the Rule of Law.

22 R. Dahl, A Preface to Democratic Theory, Chicago 2005, p. 4.

23 F.J. Yánes, Manual Politico del Venezolano, Caracas 1959. 
Moreover, democracy requires the respect for the political pluralism, which means the necessary respect of the minorities. Pluralism is, in this sense, a higher concept in democratic theory. As stated the European Court of Human Right, there can be no democracy without pluralism. According to the Court:

Pluralism and democracy are based on a compromise that requires various concessions by individuals or groups of individuals, who must sometimes agree to limit some of the freedoms they enjoy in order to guarantee greater stability of the country as a whole (decision of the Great Chamber, dated February 13, 2003, in the case of Refah Partisi [The Welfare Party] and others v. Turkey).

Political pluralism, as an inherent concept of democracy, is integrated by the following elements: (i) a society with different centers of power; (ii) political freedom that enable citizens to choose its own political decision (iii); the "right of dissidence", which means that citizens have the right to change its opinion regardless the decisions adopted by the majority; and (iii) absence of arbitrary limitation that deprives the right of dissidence. ${ }^{24}$

\section{The two "forms of democracy": the representative regimen and the political participation of the citizen. The absence of conflict between these forms}

In political theory there is a difference between the participatory democracy (similar to the "direct democracy") and the representative democracy (similar to the "indirect democracy"). Under the first model, citizens participate directly in the political decisions, and in the second model citizens elect their representatives. In the evolution of the concept of democracy, as Constant explained, ${ }^{25}$ there was a relevant different in both model. The direct democracy was based in the ancient concept of freedom that sacrifices the civil freedom in favor of the political rights. On the contrary, in the conception of freedom in the modern republics, democracy is based in the respect of the civil freedom and, as a consequence, is based primary in the representative regimes. This is why democracy and freedom coexists in a dialectic tension. ${ }^{26}$

24 According to Bobbio, only in a pluralist society the dissent is allowed. Compare: N. Bobbio, El futuro de la..., p. 73.

25 See the text of B. Constant, of 1819, The Liberty of the Ancients Compared with that of the Moderns. A version can be seen in: B. Constant, 'The Liberty of the Ancients Compared with that of the Moderns', 1819, at <http://www.earlymoderntexts.com/pdf/conslibe.pdf>, 13 July 2012.

26 There are, at least, two possible ways for approach to the relations between freedom and democracy. According to one point of view, only the "Liberal State" (Estado liberal) guarantees the freedom as a fundamental right with its own existences separate from the State. The Liberal State, as a Democratic State based on representative regime, conceived the freedom as a "natural right". This was the conception of freedom, for example, in the Constitution of Venezuela of 1811. Another way to approach this relation is to focus in the absence of real guarantees of freedom in the "Liberal State", that was, in practice, an autocratic State. The transformation of the "Liberal State" in the "Welfare State" (Estado social) changed the weakened position of freedom that now is conceived as a protected right with real content, and not only a "formal right". The "democratization" of the Welfare States helps to aim this goal. For this point of view about the relation between liberalism and democracy, see J. Ruipérez Alamillo, Libertad civil e ideología democratic, México 2008, p. 81. 
Accordingly, from the constitutional concept of democracy, there are not two different types of democracy, because the "participatory" and the "representative" models are, in the end, manifestations of democracy conceived as a whole. As Allan Brewer ${ }^{27}$ states, there is no opposition or contradiction between both models. The participatory democracy does not exclude the representative democracy: the participatory democracy is opposed to any kind of political exclusion.

In consequence, the relation of both "forms of democracy" is about evolution, not opposition. The representative democracy evolves in order to enforce the right of the citizen to participate in the political decision and to control the acts of the representatives without reducing the guarantees of the representative model, based on the freedom and in the right of the citizen to participate according to the political pluralism. In this sense, the direct participation of the citizens helps to achieve one of the main purposes of democracy: guarantee the control of the Government under the Law and in consequence, its accountability. ${ }^{28}$

The relation between the participatory and the representative democracy should be studied in Venezuela, from the perspective of the reforms that were introduced during the decades of the eighties of the past century. Carrera Damas, a former member of the Commission for the Reform of the State, stated that the purpose of such reforms was to deepen the democracy trough the formal recognition of participatory mechanisms. But there was no contradiction among these mechanisms and the representative regime. On the contrary, the reform of the State included also the transformation of the political party, the basic structure of the representative regime. The final goal was to enhance democracy as a whole, and not only to improve the quality of participatory mechanisms. ${ }^{29}$

One of the formal innovations of the Constitution of Venezuela is the recognition of the right of the citizen to the political participation (article 62). This right allows a series of additional rights, mainly, the right to vote and the right to participate in political matters. Thus, participation is regulated in two different areas: the political and the economic participation (article 70). According with this article, the political participation empowers the citizen to participate in different ways, like public audiences and deliberate communities. In the other hand, economic participation allows the citizen to exercise their economic freedom through economic organization, including those based upon the collective property, like cooperatives. The Supreme Court of Venezuela

A.-R. Brewer Carías, La democracia representativa y la falacia de la llamada "democracia participativa", México 2010.

28 For example, in the United States, administrative law evolved in order to recognize different forms for of participation of the citizens, including social organizations. It is the so called "interest-representation model", that expanded the right to participate in agency decision-making. See: R. Stewart, 'U.S. Administrative Law: a model for global administrative law ?', Law and Contemporary Problems, Vol. 68 (2005), p. 75.

29 G. Carrera Damas, 'La República liberal democrática' in F. Otamendi, T. Straka (eds.), La larga marcha de la sociedad venezolana hacia la democracia”, Venezuela: República democrática, Caracas 2011, p. 861. 
has ruled that this right must be interpreted in a broad dimension, as a democratic, elective and participatory model, based on the right of the citizens to decides when, how and for what purpose they are going to participate (sentence of the Constitutional Chamber dated January 22, 2003).

Norberto Bobbio explains that the representative democracy and the direct democracy are not two alternative systems, in the sense that one does not exclude the other", because "they are two systems that can integrate reciprocally ${ }^{30}$. In addition, according to the origins of the democracy theory in Venezuela, the representative regimes coexist with the direct participation of the citizen, as a remedy against tyranny. In resume, representative and participatory democracy are based in the whole constitutional concept of democracy, founded in freedom and political pluralism.

\section{THE DEGRADATION OF THE CONSTITUTIONAL CONCEPT OF DEMOCRACY IN THE LEGAL FRAMEWORK OF THE POPULAR POWER}

\section{The arise of the Popular Power}

"Popular Power" is a common term in political theory, as it refers to the basic and "linguistic" concept of democracy (Sartori). ${ }^{31}$ Popular Power means, in this sense, that sovereignty remains in the people that can elect their representatives. However, the concept has a very different meaning in the current and practical concept of democracy in Venezuela. In fact, "Popular Power" is one of the main instruments of the socialist model assume by President Chavez since 2005..$^{32}$ Indeed, the "National Plan for the Social and Economic Development 2007-2013", called "the first socialist Plan”, states that one of the paramount principles of the socialist model is the "participatory and protagonist democracy" based upon the Popular Power:

It is necessary to maintain the coherence between the speech about the protagonist and revolutionary democracy, on one hand, and the activities of all the institutions of the society, in the other hand, in this sense, with the continuous incentive of the democratic values, it will ensure the maintenance of popular power of the coming generations. ${ }^{33}$

Since 2007 the socialist model is based upon the Popular Power as a political organization for the construction of the "socialist society". This was the purpose of the

$30 \quad$ N. Bobbio, El futuro de la democracia..., p. 61.

31 G. Sartori, ¿Quées la..., p. 27.

32 For example, all the Ministries in Venezuela have the denomination of "Ministry of the Popular Power”. See H. Rondón de Sansó, 'Inclusión del Poder Popular en la esfera de los poderes públicos', Anuario de Derecho Público, Año 1 (2008), p. 164.

33 The original document in Spanish states "es necesario mantener la coherencia entre el discurso sobre la democracia protagónica revolucionaria, por una parte, y el proceder de todas las instituciones de la sociedad, por la otra, de esa manera, aunado al continuo incentivo de los valores democráticos, se estará garantizando el mantenimiento del poder popular de las venideras generaciones". 
rejected proposal of reform of the Constitution in 2007 and also, the meaning of the "Socialist Plan". As a result, in Venezuela the concept of Popular Power is linked with the socialist model, which is the model adopted by President Chávez and his political party, the "United Socialist Party of Venezuela".

Consequently, there is a difference between the linguist or formal concept of "Popular Power" and the "substantial matter" of that institution in Venezuela. Formally, Popular Power means the direct participation of the people in political matters, especially, trough organizations created for such purpose and based in the community. The general idea is that people have the right to organize themselves in organizations created for the political participation, including the assumption of activities that are carried out by the Administration. The Popular Power intends to describe this organization based in the right for the political participation as a manifestation of the participatory democracy.

With this "formal" idea the communal council was created in 2005 as a civil organization with its own legal existence created from a certain local community to promote the political participation in matters of the interest of the community. The council acts trough the "assembly of citizens", the higher organ of such organization. The assembly adopts the main decisions that are executed by the "Executive Unit".

From this point of view, Popular Power can be examined as a formal organization of the participatory democracy. But a deepen analysis shows its substantial matter, as an organization created for the autocratic control of the civil society.

In 2009 the National Assembly enacts a reform of the Law of the Communal Council. Article 2 of the new Organic Law of the Communal Councils stated that this organization aims to the construction of the new model of socialist society. Because of this, the legal purpose of the council is to promote the socialist model, which is the political program of the Government's party. ${ }^{34}$ Also, the new Law established controls to ensure that this purpose is achieve. The legal existence of the communal council requires an authorization granted by the "Ministry of the Popular Power for the Commune and Social Protection", an organization of the National Executive. Without that authorization - a formal registry at the Ministry - the council can not develop any activities. In order to decide about this authorization the Ministry must review, among other issues, the incorporation document of the communal council. For this purpose the Ministry elaborated an official model of this document that must be followed to obtain the authorization. In this model, the object of the communal council is the construction of the socialist model..$^{35}$ Because of this, the incorporation of the communal council - a legal requirement for the recognition of the personality of the council - should compliance with the inclusion of the "socialist model" as the sole objective of the council. ${ }^{36}$

The Laws of the Popular Power, enacted in 2010, reproduce the relations between Popular Power and socialist model. In accordance with the Organic Law of the Popular

34 See: A.-R. Brewer Carías, Ley Orgánica de los Consejos Comunales, Caracas 2010.

35 For the official model see: at <http://www.mpcomunas.gob.ve/contenido.php?id=214>, 12 July 2012.

36 See: C. Nikken, 'Ley Orgánica de los Consejos Comunales y el Derecho a la participación ciudadana en los asuntos públicos' in Leyes Orgánicas del..., p. 185. 
Power, the Popular Power is defined as the full exercise of sovereignty by the people in political, economic, social, cultural, environmental and international matters, in any area of the development of society, through its various and dissimilar forms of organization, that build the Communal State (article 5). The Popular Power is based on certain "organizations" enumerated in article 15 of the Law: the communal council; the commune; the communal city, and the "system of communal aggregation" (communal federation and confederation). All these organizations must be registered in the Ministry that also will supervise its activities.

In addition, the legal purpose of the "organization" of the Popular Power is, according to article 6 of the Law, impulse the strengthening of the organization of the people, in order to consolidate the protagonist and revolutionary democracy, and build the foundations of socialist society, democratic, by the law and by the justice. ${ }^{37}$

As we can see, Popular Power is not the consequence of the free of political participation of the citizen, but a political organization controlled by the Government according with its political doctrine, the socialism. ${ }^{38}$ This is why the Commune - another of the "subjects" of the Popular Power - is described by the Organic Law of the Commune as a socialist space, a local entity oriented to the construction of the socialism (article 5). The Commune can be defined, in a simple way, as an aggregation of communal councils oriented to the construction of the socialist. This organization requires, also, an authorization of the Ministry that will supervise if its object is the promotion of the socialism. ${ }^{39}$ The Commune is, in resume, a main organization of the Communal State, and in consequence, a support for the construction of the socialist society (article 7)..$^{40}$

The Popular Power is the foundation of a "new" model of State, the so-called Communal State defined in article 8.8 of the Organic Law of the Popular Power as a political and social organization aimed to the construction of the socialist society. ${ }^{41}$ The Communal State is a "parallel" State different from the State contemplated in the Constitution. An example of the relation between the "Constitutional State" and the "Communal State" can be represented in this graphic. ${ }^{42}$

37 The original version in Spanish states the following: "impulsar el fortalecimiento de la organización del pueblo, en función de consolidar la democracia protagónica revolucionaria y construir las bases de la sociedad socialista, democrática, de derecho y de justicia".

38 About the concept of Popular Power in Venezuela, also see: M. Rachadell, Socialismo del Siglo XXI. Análisis de la reforma constitucional propuesta por el Presidente Chávez en agosto de 2007, Caracas 2007.

39 Also, the official model of the incorporation document of the Commune establishes the socialism as the object of this figure: at <http://www.mpcomunas.gob.ve/contenido.php?id=214>, 12 July 2012.

40 About the concept of Commune in Venezuela, see: A. Vigilanza, 'La descentralización política de Venezuela y las nuevas Leyes del Poder Popular' in Leyes Orgánicas del Poder..., p. 477.

41 The creation of a Communal State was an idea contemplated in the rejected Project of reform of the Constitution. Nevertheless, this idea was developed in the Organic Law of the Popular Power. See: G. Tarre Briceño, 'La nueva geometría del poder', Revista de Derecho Público, № 112 (2007), p. 115.

42 According with the Constitution, Venezuela is a "Federal State", with this basic organization: the Republic, the States of the Federation and the Municipalities. The Municipality is "the basic political 


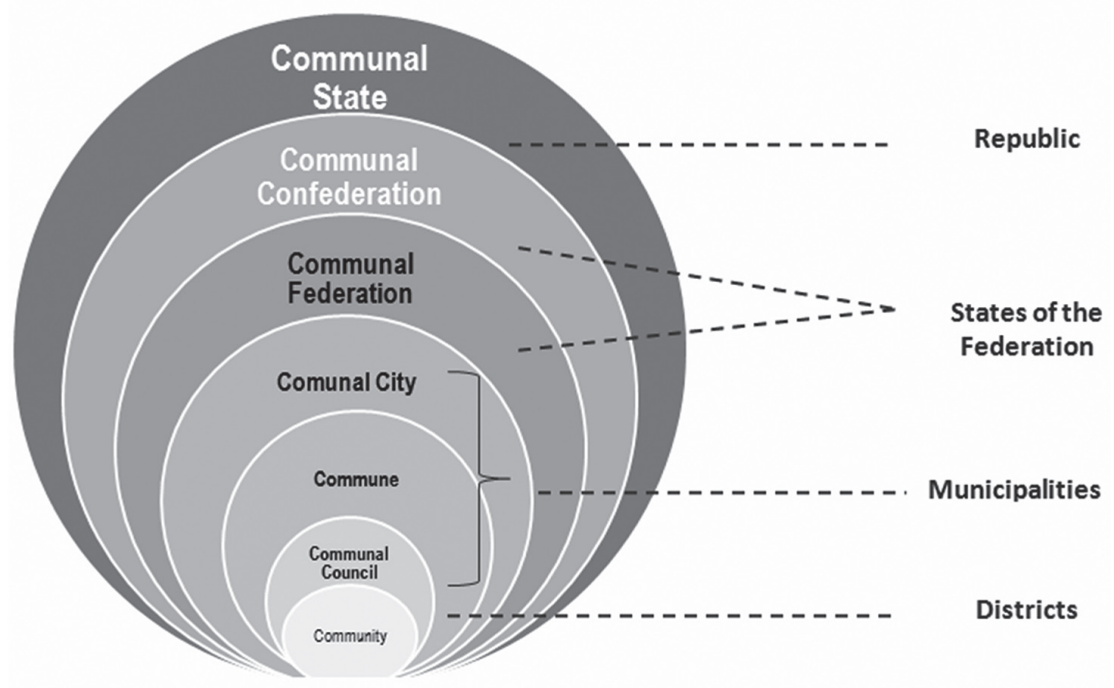

The so-called "Communal State" is based in this principle: popular sovereignty must be exercises with the exclusive objective of the promotion of the socialism. The word "socialism" has, here, a very specific meaning. According with article 8 of the Organic Law of the Popular Power, socialism is a model of social relationship of production centered in the coexistence solidarity and satisfaction of tangible and intangible needs of society. This is the political doctrine of the Government's party, the United Socialist Party of Venezuela. This party - according to its "red book" - must impulse the direct participation of the people for the construction of the socialism trough the Popular Power. ${ }^{43}$

In conclusion, the political participation of the citizen trough the Popular Power has these characteristics:

In the first place, citizens can only participate through some of the "subjects" of the Popular Power, and mainly through the communal council and the commune. Citizens do not have the right to choose how to participate, because they can only participate

unity" of the political-territorial organization. Within the Municipality there are different local entities, like the District ("Parroquias"). This organization is founded in the decentralization that intends to "bring power to the people" according with the political freedoms. In contrast, the Communal State is based upon the community and the communal council as a socialist organization. As a consequence, in this Communal State, decentralization is not a policy founded in the strengthening of the democracy but in the transfer of competence form the States of the Federation and Municipalities to the "organization" of the Popular Power in order to promote the socialism, under the control of the Government. See my previous analysis in J. Hernández, 'Descentralización y Poder Popular' in Leyes Orgánicas del..., p. 459. In 2012 the President enacted the Decree with Rank, Value and Force of Organic Law for the Communal Management of Competence that regulates the transfers of competence from the States and Municipalities to the organization of the Popular Power, under the supervision of the Government.

43 The "red book" ("Libro Rojo") is the official compilation of the political principles of the United Socialist Party of Venezuela. See PSUV, 'Libro Rojo', at <www.psuv.org.ve>, 5 July 2012. 
via some of the "subjects" of the Popular Power that must be authorized by the National Executive. Without this authorization, those "subjects" will not have legal existence. ${ }^{44}$

In the second place, citizens do not have the right to choose in which way they will exercise their political freedoms. Under the Organic Law of the Popular Power there is only one way: the promotion of the socialism as the political doctrine of the Government. The Law did not recognize the political participation for other purpose, not even the political participation against the socialism. Socialism is, in this sense, the political doctrine of the State. As I explain in the next section, this is openly contrary to the Constitution.

\section{The socialism as the political doctrine of the State trough the Popular Power. The violation of the constitutional democracy}

Since the assumption of the socialism as the political ideology of President Chávez, democracy is severely weakened. There is a sharp contrast between the meaning of democracy under the Popular Power and the constitutional concept of democracy. In the current political regime, democracy means the participation of the citizen through the Popular Power for the promotion of the socialism. This practical idea of democracy does not recognize the existence of other ideology and not even the existence of a democratic opposition. For example, recently President Chávez has stated that only the people that support him are "patriots". ${ }^{4}$

On the contrary, as we explained, the constitutional concept of democracy is based in freedom and pluralism, principles that requires the recognition of all the ideologies admitted upon the Constitution, including the political opposition to the Government. The absence of pluralism in the legal framework of the Popular Power prevents that such figure could be considered as a manifestation of the constitutional democracy. There is a clear explanation for that conclusion: the legal framework of the Popular Power is consistent with the rejected proposal of the constitutional reform, but not with the Constitution of 1999 , that is based in the political pluralism and the political freedoms of citizens. As a consequence, the current language of the democracy is the language of the rejected proposal of constitutional reform, in which the State was conceived as a "Socialist State" and the political participation of the citizen was reduced upon the Popular Power to the promotion of the socialism.

In resume, the legal configuration of the Popular Power violates the constitutional concept of democracy for these reasons:

In first place, the Laws of the Popular Power violates the right of political participation (articles 62 and 70 of the Constitution), because such participation is not free but

44 Because of this, the communal councils that did not have recognized the socialism in its incorporation document have had several problems in order to obtain the authorization of the Ministry. In some cases, the communal council sued the Government at the Tribunals in order to obtain such act. See sentence dated 31 May 2011, by the Corte Primera de la Contencioso Administrativo.

45 See E. Rojas, 'Anyone that did not support Chávez is not a patriot', El Universal, at <http://www. eluniversal.com/blogs/sobre-la-marcha/120727/el-que-no-es-chavista-no-es-patriota>, 27 July 2012. 
subordinated to a single model. Citizens can only participate for the construction of the "socialist society" and through the authorized organizations of the Popular Power.

Secondly, the Laws of the Popular Power breach the political pluralism and, as a consequence, violate the constitutional concept of democracy in Venezuela. The political pluralism, based in the right of dissent, is diminishes in the legal framework of the Popular Power, that only recognized the participation for the promotion of the socialist model, which is the doctrine of the Government's party.

In third place, the violation of the constitutional concept of democracy is even more evident if we consider that the Popular Power is the main vehicle for the participation of the citizens in several matters. For example, the decentralization mainly proceeds through the transfer of competence from the State to the organization of the Popular Power, including the grant of economic resources. ${ }^{46}$ Furthermore, citizen can only participate in the transfers of services from the State through an organization of the Popular Power. ${ }^{47}$ Therefore, in the practice, if citizens want to participate in political matters, they should create an organization of the Popular Power, like the communal council. In such a way, citizens would be compelled to support the socialism, even against their will.

According to Inter American Court of Human Rights, in the case Yatama $v$. Nicagarua (dated June 23, de 2005), there cannot be any limitation to the whole content of the political rights, in a manner that their regulation constituted an impediment for the citizen to participate freely in the conduction of the State. In other words, the limitations of political rights cannot deprive the freedom of the citizen to choose how, when and with what purpose they will participate.

The legal framework of the Popular Power deprives such right, because citizen can only participate through the legal organizations of the Popular Power for the promotion of the socialist. This is the typical example of the totalitarianism regimes that only admitted a single political ideology, based in the "duplications" of political organizations, from the State and from de party. ${ }^{48}$ As Aron explained, this is the case of the so-called "popular democracies" based on the "socialist society", in which the State invades the whole ambit of liberty with a "sole political doctrine". 49

We must remember that the organizations of the Popular Power (like the communal council) are subject to the control of the National Government, and only can exercises its activities to seek the construction of the socialism, that is the political doctrine of

46 The reduction of the concept of decentralization to the transfers of competence to the Popular Power is regulated in the Organic Law of the Federal Government Council. According with this Law, decentralization is aimed to the promotion of the socialism. Compare: J.D. Alfonso, El régimen de los Estados vs. la centralización de competencias y de recursos financieros, Caracas 2011.

47 The Decree with Rank, Value and Force of Organic Law of the Communal Management of Competences states that the Administration can transfers the exploitation of economic activities, but only to organizations of Popular Power.

48 Compare: H. Arendt, Los orígenes del totalitarismo, México 2004, p. 479. The author explains that one of the characteristics of the totalitarian regimes is the existence of a "dual authority", the authority of the State and the authority of the Government's party. Each function of the Administration is duplicated by a political organization of the Government's party.

49 Compare: R. Aron, Introducción a la filosofía politica. Democracia y revolución, Madrid 1997, p. 215. 
the Government's party, called the "Unitary Party". Also, there is a tendency to duplicate the bureaucratic structures of the Administration by "special" organizations that depends on the political control of the President, as vehicles to enforce the socialist model. ${ }^{50}$ The final result is that the individual is substituted by the political configuration of the Popular Power.

There are comparatives examples of such vision of "democracy". Article 3 of the Constitution of Cuba, for example, states that in the Republic of Cuba sovereignty lies in the people, from whom originates all the power of the state. That power is exercised directly or through the assemblies of People's Power and other state bodies which derive their authority from these assemblies, in the form and according to the norms established in the Constitution and by law. The notion of "People's Power" is very similar to the concept "Popular Power" in Venezuela.

Another historic example that we can fund in comparative law, is the figure of the "soviets", in the former Union of Soviet Socialist Republics (USSR). ${ }^{51}$ Those soviets were "councils", a collective organization that seeks the construction of socialism. The Constitution of the USSR of 1936 stated, in article 3, that in the U.S.S.R. all power belongs to the working people of town and country as represented by the Soviets of Working People's Deputies. The formal explanation about the soviets was that this organization was an expression of the "direct democracy". The practice, as historical evidence proofs, shows that such organization was an instrument for the political control of the society. ${ }^{52}$

50 Since 2004, President Chávez created a parallel Administrations, called "missions" (Misiones), that are organizations that depends on the direction of the President, to develop social activities in areas such education and housing, for the promotion of the socialism. These missions, along with the organizations of Popular Power constitute a "new" form of political organization of the "new" State, the so called Socialist State. Compare: A.-R. Brewer Carías, Una nueva tendencia en la organización administrativa venezolana: las "misiones" $y$ las instancias y organizaciones del "Poder Popular" establecidas en paralelo a la Administración Pública, Caracas 2011.

51 One example of the use of the republican language for other purpose, can be seen in the article written in 1932 by A. Nin, about The Soviets: its origin, development and functions. According with this author, the regime of the soviets is not an "artificial creation" but the result of the workers and the "most perfect realization of democracy". This model of "direct democracy" was opposed to the "representative democracy”, considered a bourgeois democracy. See: A. Nin, 'Los Soviets: Su origen, desarrollo y funciones', 2006, at <http://www.marxists.org/espanol/nin/1932/soviets.htm>, 12 July 2012. As Lenin stated, we, however, shall break with the opportunists; and the entire class-conscious proletariat will be with us in the fight-not for a "shifting of the relation of forces," but for the overthrow of the bourgeoisie, for the destruction of bourgeois parliamentary, for a democratic republic of the Commune type, or a republic of Soviets of Workers' and Soldiers' Deputies, for the revolutionary dictatorship of the proletariat (V. Lenin, The state and revolution, 1976, p. 52. See at: http://www.marxists.org/archive/lenin/works/1917/staterev/). About the constitutional organizations of the soviets, see M. García-Pelayo, 'Derecho constitucional comparado' in idem, Obras Completas, Vol. 1, p. 704. According with García-Pelayo, the Constitution of 1936 contemplated a "radical democracy" without political freedom, because only one party - the "communist party" - was admitted. The basic figure of this system was the "soviets", defined as councils that derivates from the direct democracy of the "working class". In resume, according with the author, this was not a "standard western democracy" but a "socialist democracy" (p. 705).

52 The "contradiction" between the "direct democracy" and the "representative regime", is a common point in the political doctrine of the socialism, founded in the "total citizen" that led to the "total State". See N. Bobbio, El futuro de..., p. 50. 
The legal framework of the Popular Power, at least, is very similar to those "popular democracies", because it is based in organizations that act under the political control of the Government to comply with its political doctrine, the socialism. This organization cannot be considered as a manifestation of democracy, not even a manifestation of the "direct democracy", because the lack of freedom in the Popular Power. Democracy is not the mere participation of citizens in political and economic matters: it must be understood as the participation based on the freedom and, in consequence, in political pluralism.

The regulation of the Popular Power in Venezuela poses several problems about the comprehension of the meaning of democracy. In the language of the Laws of the Popular Power, democracy is conceived as the opposite of the "representative regime", and as a vehicle for the construction of the socialist society. This constitutes a risk of deformation of the language of democracy. Because of this, I must insist that according to the Constitution of Venezuela, the democracy must be based in two basic principles, which are the political freedom of the citizen and the pluralism.

\section{THE NECESSARY REFORMULATION OF THE POPULAR POWER IN VENEZUELA}

Is the Popular Power an unconstitutional figure? Yes, it is, according with its legal framework. But in the background, the existence of a civil organization that promotes the participation of citizen in political matters is an idea compatible with the constitutional concept of democracy. So, in the end, the objections over the Popular Powers can be resumed in three aspects: (i) the intense control that the Government exercises upon these organizations; (ii) the mandate of the Law that imposes the socialism as the sole objective of the Popular Power, and (iii) the exclusion of other forms of participation and, especially, the exclusion of ideologies different than the socialism.

But aside these objections, political freedom of citizens allows the voluntary creation of council and other subjects similar to the organizations of the Popular Power, even for the promotion of the socialism. Also, the existence of a council based upon certain community (similar to the communal council) is not an idea opposite to the constitutional concept of democracy. On the contrary, those organizations can be a legitimate vehicle for the political participations. But neither the promotion of the socialism nor the organization of council should be a mandatory conduct imposed by the Law.

The reformulations of the Popular Power, in consequence, demanded the modification of its legal framework, in order to (i) diminish the control of Government, that must be in any case, a simplified control of the Local Government; (ii) the elimination of any imposition about the socialism or any other ideology and (iii) the elimination of any exclusion of other forms of political participation. Citizens must have the right to select the legal form through which they will participate. This principle requires ensuring equality of treatment of all the mechanism of political participation. Citizens that choose not to participate through a "council" for the promotion of socialism cannot be discriminated. 
The main problem is that the legal framework of the organizations of the Popular Powers, deliberated misunderstood the language of democracy, in order to use such language to implement a model based in the centralized control of the society by the Government. The legal framework of the Popular Power shows that the differences between Government and civil society have diminished. According to perspective of such Laws, the individual is submerged in the control of the State, to the extent that the political participation necessarily focuses on the doctrine of the Government. The society is not free, in this perspective. On the contrary, the society is used as an instrument for the political control of the Government. It has even been doubted whether these organizations are part of private sector, due to its strong relations with the Government. According to the Law that regulates the judicial control of the Administration, ${ }^{53}$ the communal council could be considered as a public office, which reflects that the Popular Power is acknowledge as a part of the State.

There is a historical tradition in Venezuela based in the manipulation of the language of the Liberal Republic and the democracy for support autocratic regimes or autocratic measure. Luis Castro Leiva stated, in this sense, that the "republican language" was destroy in the uses and practices of the autocratic regimes developed in Venezuela centered in the charismatic personality of the "leader", than invokes constantly the works and thought of Simón Bolívar, the Liberator ${ }^{54}$, as happens with President Chávez. ${ }^{55}$ In my opinion, the legal framework of the Popular Power is a consequence of that perspective, because those Laws uses the language of the "participatory democracy" to build and institution focus in the central and political control of the free society. One example of that is article 5 of the Organic Law of the Popular Power, according to which the organization and participation of the people in the exercises of their sovereignty is inspire in the doctrine of the Liberator Simón Bolivar. The "Bolívar's cult" is an historic example in Venezuela of the use - and manipulation - of the figure of Bolívar by autocratic regimes. ${ }^{56}$

The manipulation in the use of the language of the democracy demonstrates, according with Ferrajoli, that democratic methods could destroy the own methods of democ-

53 See: 'Ley Orgánica de la Jurisdicción Contencioso-Administrativa', of 2010. The communal council could be controlled by the same Tribunals in charge of the judicial review of Administration.

54 L. Castro Leiva, 'Las paradojas de las revoluciones hispanoamericanas' in Luis Castro Leiva. Obras, Vol. 2: Lenguaje republicanos, ed. C. Leal Curiel, Caracas 2009, p. 97.

55 As J. Lynch stated: in 1998 Venezuelans were astonished to learn that their country had been renamed the Bolivarian Republic of Venezuela, by decree of President Hugo Chávez, who called himself a revolutionary Bolivarian. Authoritarian populist, or neo-caudillos, or Bolivarian militarist, whatever their designation, invoke Bolivar no less ardently that did their previous rulers, though it is doubtful whether he would have responded to their calls" (J. Lynch, Simón Bolivar. A life, New Haven 2006, p. 304). The rename of Venezuela was not a consequence of a Decree of President Chávez, but a decision of the then constitutional assembly. Nevertheless, the new name of the country was an idea of Chávez that was initially rejected by the assembly, but later accepted, probably, as a demonstration of fidelity of Chávez's idea by the majority of the members of such assembly, that were members of the political party of Chávez.

56 Compare: G. Carrera Damas, El culto a Bolivar, Caracas 2006 and E. Pino Iturrieta, El divino Bolivar, Caracas 2006. 
racy, as happened with the totalitarian terrible experiences. Because of this, there is neither popular sovereignty nor democracy without individual freedom. ${ }^{57}$

At the end, the legal configuration of the Popular Power leads to the "Omnipresent Government", an expression of L. Von Mises. ${ }^{58}$ The Government is omnipresent because there is no formal distinction between the society and the Sate. On the contrary, Government and citizens are instruments for the construction of the socialism, as the State's sole doctrine. The objections about the representative regime did not result in the strengthening of democracy but its gradual diminishes.

It is necessary to overcome such perspective and reformulate the Popular Power on the basis of freedom and pluralism. But this purpose would require a bigger effort, because the whole politic system of the current National Government is based on the same distorted vision of the Popular Power. This is current the crossroads of democracy in Venezuela: the distinction between the path of the Popular Power that is focuses in the political control over the society aimed to the construction of the socialism, and the path of freedom and political pluralism within the Constitution of $1999 .{ }^{59}$

La Unión, Venezuela, February-July 2012

\section{REFERENCES}

Alfonso J.D., El régimen de los Estados vs. la centralización de competencias y de recursos financieros, Caracas 2011.

Arendt H., Los origenes del totalitarismo, México 2004.

Aron R., Introducción a la filosofía politica. Democracia y revolución, Barcelona 1999.

Baptista A., El relevo del capitalismo rentístico. Hacia un nuevo balance de poder, Caracas 2004.

Bobbio N., El futuro de la democracia, México 2008.

Brewer Carías A.-R., Golpe de Estado y proceso constituyente en Venezuela, México 2002.

Brewer Carías A.-R., Historia Constitucional de Venezuela, Vol. 2, Caracas 2008.

Brewer Carías A.-R., 'Introducción general al régimen del Poder Popular y del Estado Comunal' in Leyes Orgánicas del Poder Popular, Caracas 2010.

Brewer Carías A.-R., La democracia representativa y la falacia de la llamada "democracia participativa", México 2010.

Brewer Carías A.-R., La reforma constitucional de 2007. (Comentarios al proyecto inconstitucionalmente sancionado por la Asamblea Nacional el 2 de noviembre de 2007), Caracas 2007.

Brewer Carías A.-R, Ley Orgánica de los Consejos Comunales, Caracas 2010.

Brewer Carías A.-R., Problemas del Estado de partidos, Caracas 1988.

57 L. Ferrajoli, Principia iuris. Teoria..., p. 11.

58 L. von Mises, Omnipotent Government. The Rise of the Total State and Total War, New Haven 2010.

59 Compare: A.-R. Brewer Carías, Venezuela under Chávez. Blurring between democracy and dictatorship?, Philadelphia 2009. 
Brewer Carías A.-R., Una nueva tendencia en la organización administrativa venezolana: las "misiones" y las instancias y organizaciones del "Poder Popular" establecidas en paralelo a la Administración Pública, Caracas 2011.

Brewer Carías A.-R., Venezuela under Chávez. Blurring between democracy and dictatorship?, Philadelphia 2009, at: http://www.allanbrewercarias.com/Content/449725d9-f1cb-474b-8ab2-41 efb849fea2/Content/I,\%201,\%20989.\%20VENEZUELA\%20UNDER\%20 CHAVEZ.\%20BLURRING\%20BET WEEN\%20DEMOCRACY\%20AND\%20 DICTATORSHIP.\%20Pennsylvania\%20Law\%20April\%202009.\%20l.pdf.

Caballero M., La historia de los Venezolanos del siglo XX, Caracas 2011.

Carrera Damas G., El culto a Bolivar, Caracas 2006.

Carrera Damas G., La Primera República Liberal Democrática 1945-1948, Caracas 2008.

Carrera Damas G., 'La República liberal democrática' in F. Otamendi, T. Straka (eds.), La larga marcha de la sociedad venezolana hacia la democracia”, Venezuela: República democrática, Caracas 2011.

Castro Leiva L., 'Las paradojas de las revoluciones hispanoamericanas' in Luis Castro Leiva. Obras, Vol. 2: Lenguajes republicanos, ed. C. Leal Curiel, Caracas 2009.

Combellas R., 'El proceso constituyente y la Constitución de 1999' in E. Plaza, R. Combellas (coords.), Procesos constituyentes y reformas constitucionales en la historia de Venezuela 1811 -1999, Vol. 2, Caracas 2005.

Constant B., 'The Liberty of the Ancients Compared with that of the Moderns', 1819, at <http://www.earlymoderntexts.com/pdf/conslibe.pdf>, 13 July 2012.

Dahl R., A Preface to Democratic Theory, Chicago 2005.

Delfino M. de los Ángeles, 'La involución de la descentralización' in M. de los Ángeles Delfino, M. Rachadell, Descentralización y Centralización del Poder en Venezuela, Caracas 2009, Fundación Manuel García Pelayo, Colección Cuadernos del Centenario, № 11.

El Troudi H., La politica económica bolivariana (PEB) y los dilemas de la transición socialista en Venezuela, Caracas 2010.

Ferrajoli L., Principia iuris. Teoría del derecho y de la democracia, Vol. 2, Madrid 2011.

Ferrajoli L., 'Sobre la definición de democracia. Una discusión con Michelanagelo Bovero', Isonomía, № 19 (2003).

García-Pelayo M., 'Derecho constitucional comparado' in M. García-Pelayo, Obras Completas, Vol. 1, Madrid 2009.

García-Pelayo M., 'Las transformaciones del Estado contemporáneo' in M. García-Pelayo, Obras Completas, Vol. 2, Madrid 1991.

Hernández G.J., 'Descentralización y Poder Popular' in Leyes Orgánicas del Poder Popular, Caracas 2010.

Lenin V., The state and revolution, 1976, at <http://www.marxists.org/archive/lenin/works/ $1917 /$ staterev/>.

'Ley Orgánica de la Jurisdicción Contencioso-Administrativa' of 2010.

Linares Benzo G., 'Sólo un Poder Público más. El Poder Popular en la Reforma de 2007', Revista de Derecho Público, No 112 (2007).

Lynch J., Simón Bolivar. A life, New Haven 2006.

Mises L. von, Omnipotent Government. The Rise of the Total State and Total War, New Haven 2010. 
Nikken C., 'Ley Orgánica de los Consejos Comunales y el Derecho a la participación ciudadana en los asuntos públicos' in Leyes Orgánicas del Poder Popular, Caracas 2010.

Nin A., 'Los Soviets: Su origen, desarrollo y funciones', 2006, at <http://www.marxists.org/espanol/nin/1932/soviets.htm>, 12 July 2012.

Njaim H., 'La democracia participativa, de la retórica al aprendizaje', Boletín de la Academia de Ciencias Politicas y Sociales, No 143 (2005).

Partido Socialista Unido de Venezuela, 'Libro Rojo', at <www.psuv.org.ve>, 5 July 2012.

Pino Iturrieta E., El divino Bolivar, Caracas 2006.

Rachadell M., Socialismo del Siglo XXI. Análisis de la reforma constitucional propuesta por el Presidente Chávez en agosto de 2007, Caracas 2007.

Rojas E., 'Anyone that did not support Chávez is not a patriot', El Universal, 27 July 2012, at <http://www.eluniversal.com/blogs/sobre-la-marcha/120727/el-que-no-es-chavista-no-es-patriota>.

Rondón de Sansó H., 'Inclusión del Poder Popular en la esfera de los poderes públicos', Anuario de Derecho Público, Año 1 (2008).

Ruipérez Alamillo J., Libertad civil e ideología democratica, México 2008.

Sartori G., ¿Qué es la democracia?, Madrid 2003.

Stewart R., 'U.S. Administrative Law: a Model for Global Administrative Law?', Law and Contemporary Problems, Vol. 68 (2005).

Tarre Briceño G., 'La nueva geometría del poder', Revista de Derecho Público, No 112 (2007).

'Venezuela. Official model of the Communal Council', at <http://www.mpcomunas.gob.ve/ contenido.php?id=214>, 12 July 2012.

'Venezuela. Presidential Comission for the Reform of the State', Antecedentes de la reforma del Estado, Caracas 1990.

Venezuela. Sentence dated 31 May 2011, by the Corte Primera de la Contencioso Administrativo.

Vigilanza A., 'La descentralización política de Venezuela y las nuevas Leyes del Poder Popular' in Leyes Orgánicas del Poder Popular, Caracas 2010.

Yánes F.J., Manual Politico del Venezolano, Caracas 1959.

José Ignacio HERNÁNDEZ G., Director of the Public Law Studies Center of the Universidad Monteávila; Administrative Law Professor at Universidad Central de Venezuela and at Universidad Católica Andrés Bello. 